\title{
Impact of Ethical Leadership on Employees Helping Behavior: Role of Moral Attentiveness and Moral Courage
}

\author{
IMRAN YOUSAF \\ International Islamic University, Islamabad \\ Email: imranyousaf@iiu.edu.pk \\ Tel: +923225100500 \\ TASNEEM FATIMA \\ International Islamic University, Islamabad \\ Email: tasneem.fatima@iiu.edu.pk \\ Tel: +923222206611 \\ ALI HAIDER \\ International Islamic University, Islamabad \\ Email: eelihaider@iiu.edu.pk \\ Tel: +923335402016
}

\begin{abstract}
In the overriding context of massive risk, leaders are faced with the tough decision of making ethically sound decisions. By acting with moral courage, leaders couple managerial decisions with ethical principles, bringing long-term benefits for the organization. Researchers proposed that leaders with moral courage will be seen as ethical role models by their followers, who as a result, will be increasingly motivated to replicate their behavior, ensuring they do the right thing for their organization in due time. Bandura's Social learning theory has been deployed to explain the proposed theoretical framework. The theoretical framework of this study was tested by collecting data from the employees of education sector (Both Public and Private), all located within twin cities. Results indicated mediation effects of moral attentiveness and moderation of moral courage in the relationship of ethical leadership and helping behavior.
\end{abstract}

Keywords: Moral Attentiveness, Moral Courage, Ethical Leadership, Helping Behavior.

\section{Introduction}

Leadership research has highlighted its constructive and positive role in the organizations including employees positive work behaviors. In the context of highly competitive business world ethical decision making and ethical behavior has been identified as important concerns for researchers and practitioners. Ethical leadership has been emerged as one of most important factors that have the potential to trigger ethical and positive behaviors at work. In a recent meta-analytic review (Bedi, Alpaslan, \& Green, 2016), it is urged to examine positive consequences of ethical leadership. Although many recent studies examined antecedents and outcomes of ethical leadership but there is still a further need to comprehend that how individual-level mechanisms triggered by ethical leadership persuade employee outcomes (Changsuk, Jianhong, Bartnik, Haney \& Mingu, 2017). "Moral attentiveness is a general state of chronic engagement with moral stimuli" (Reynolds, 2008). Moral attentiveness has been broken down into two different perspectives: reflective and perceptual moral attentiveness (Whitaker \& Godwin, 2013). In reflective moral attentiveness, moral matters of daily significance are the focus of the study. Whereas, in perceptual moral 
attentiveness, the moral underpinnings that govern the environment in which these matters unfold are analyzed (Reynolds, Owens, \& Rubenstein, 2012; Sturm, 2017). Moral attentiveness give rise to a cognitive process where employees may be able to build up their moral potency.

In the overriding context of massive risk, leaders are faced with the tough decision of making ethically sound decisions (Den Hartog, 2015). Organizations with dynamic environment give rise to ambiguity and risk where decision makers continuously find themselves in the grey areas of judged wrong even morally corrupt (Palanski, Cullen, Gentry, \& Nichols, 2015). Moral Courage of a leader in these situations can only provide path to the sound decision making, where one is willing to take steps to maintain the balance (Kidder, 2005). Moral Courage is comprised of complex ethical competencies and knowledge that enhances the ability of the individual with the will and desire to surpase the surging pressures of obstacles and the personal career threats for moral application (Sekerka, Bagozzi, \& Charnigo, 2009).

Organizational Leaders by practicing moral courage are in a better position to take ethical decisions incongruence with the accepted ethical principles, in return these ethical decisions bring long run benefits to the organization (Simola, 2018). The buzz of morality and the moral values of the leaders has been around for quite long but only few studies (Peng \& Lin, 2017; Pircher Verdorfer \& Peus, 2019; Zheng et al., 2015), tried to find connection on the employees attitudes and their moral training (Palanski et al., 2015). In nutshell, there is lesser evidence on its influence on a variety of variables, especially group prosocial outcomes, which are directly responsible for nurturing the ability to collectively respond in discretionary helping behaviors. This research suggests that: leaders imbued with moral courage will be seen as ethical role models by their followers, who as a result, will be increasingly motivated to replicate their behavior, ensuring they do the right thing for their organization in due time.

Based on the extent of employee willingness, Tyler and Blader assigned rule-following behavior (RFB) into two different components: conformity and voluntary deference to organizational paradigms.(DeHartDavis, 2017). Tyler and Blader (2005) explained RFB as self motivated or reinforced conformance with the policies and procedures of the organization. The further suggested that type of motivation either intrinsic or extrinsic will explain the process of RFB. Therefore, on the basis of driving forces of Intrinsic and Extrinsic motivation RFB is divided into Intrinsic rue following behavior (IRFB) and extrinsic RFB (ERFB). IRFB deals with the subject's behavioral motivations to willingly conform to the policy's requirements. So, IRFB, in essence, taps into the intrinsic will of the subject and is, therefore, conformity in the real sense. It mines the subject's intrinsic values, such as persistence and initiative for organizational application.

\section{Underpinning Theory}

Bandura (1977, 1986) Social Learning Theory (SLT) has been deployed to explain the proposed theoretical framework. According to Bandura's (1971), Social Learning Theory is the study of acquiring new behaviors by the sole applications of imitation and observation. An integral component in social learning theory is reciprocal determinism, which states that learning is the direct outcome of cognitive processes unraveling and subsequently being learned in a social setting.

According to social learning theory of (Bandura's, 1977) people will not directly imitate the behaviour of their role model to shape their own desired positive or negative actions it depend on the mechanism between the stimuli and responses. When people will monitor their stimuli like their role model or leader behaviour which is according to the value of internal function or match with the worth of organization and extensively acceptable then due to cognitive thinking of individual certain feelings, emotion or intuitions will evoke to appraise the behaviour of their model and decide either to imitate or not. When people will imitate their role model or stimuli behavior due to the positive feeling, emotion or intuition about the role model behavior then they will be motivated to act accordingly as similar to their role model. 
Embedding social learning in the proposed model, we argue that employees learn from the ethical leader as their role models and indulge in moral attentiveness as cognition process. According to Social learning theory (Bandura's, 1977) workplace environment \& role model are motivational as well as social factors that affect learners/individuals cognitive process of learning to learn \& adopt certain behaviors. In line with the theory they further imitate the behavior of ethical leader in the form of helping behavior at workplace. We further suggest that employees who are more morally courageous by disposition, they show more helping behaviors.

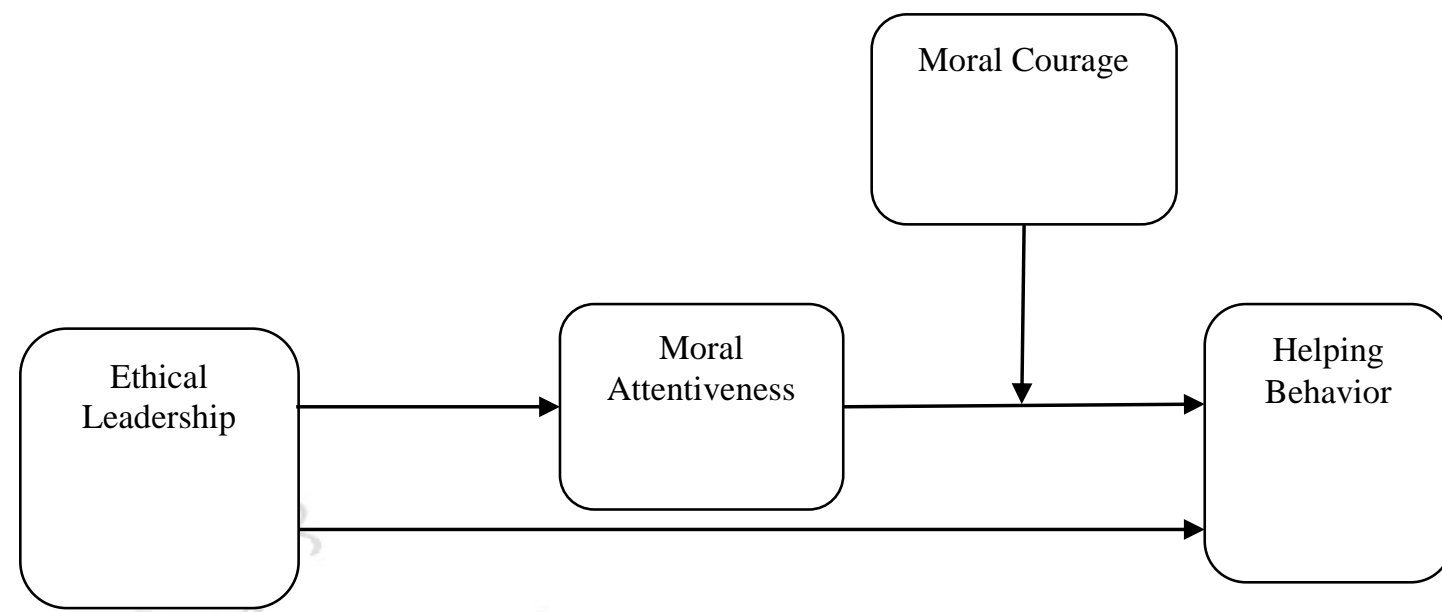

Figure 1: Proposed Theoretical Framework

\section{Literature Review and Hypotheses Development}

\section{Ethical Leadership and Helping Behavior}

Since many years, ethical leadership has been defined by the researchers as normative and descriptive (Ciulla, 2009). The main emphasis of normative form of ethical leadership has been on moral principles and argument, which help the leaders in making ethical decisions by modifying their leadership styles (Chughtai \& Mayer 2015). The other form of ethical leadership style is descriptive which explicate that being fair, honest and principled individuals is supposed to be an ethical leader who influence their follower's through communication with them and display ethical behaviour by rewards and punishments (Brown et al. 2011). As emerging trends of leadership considered that virtue and morality are two vital aspects of ethical leadership. According to Hartog \& Hoogh (2016), workers who recognize their leaders as moral person have a propensity to demonstrate more pro-social attitudes such as increased level of citizenship deeds, organizational loyalty and job fulfilment.

Bavik et al., (2017), states that the moral aspects of ethical leadership focuses on faithfulness, veracity, fairness in treatments, and principled decision-making. Ethical leaders are also acknowledged as moral people and moral managers (Trevino, Hartman, \& Brown, 2006).

Helping behavior, a pivotal factor in OCB, has also been widely explored in organizational behavioral research (N. P. Podsakoff et al., 2014;). Previous research s evident that leaders are the key sources who can inculcate helping behaviors among subordinates who are in the position to associate this helping behavior with rewards (Podsakoff et al., 2000). We argue that like authentic leadership (Hirst, Walumbwa, Aryee, Butarbutar, Jeffery \& Chen, 2016), ethical leadership instill helping behaviors among subordinates. Ethical leaders build a trusting environment (Moorrman, eta 1, 2000) due to their ethical behavior with subordinates that help employees to trust them and become helping to their peers. As per social learning theory people replicate the behaviors, they learn from their role models and environment. The concern of 
employees with reference to their moral self and values can be solved through the ethical leadership style (Mayer, Kuenzi, Greenbaum, Bardes, \& Salvador, 2014). As the ethical leaders possess truthfulness, veracity, fairness in treatments with concern for others, the subordinates learn these behaviors and try to replicate in the form of helping behaviors.

H1: Ethical leadership is conducive to an employee's helping behavior.

\section{Ethical Leadership and Moral Attentiveness}

Ethical leaders are those influential authorities whose conducts are based on moral philosophy (Trevino, Hartman, \& Brown, 2014). Ethical leadership is an individual's display of acquired morality through his own subtle actions and interpersonal interactions with the organizational environment (Dulebohn \& $\mathrm{Wu}$, 2016).

Employees show higher levels of work related happiness and low levels of stress with less negativity under the ethical guidance from their leader (Schaufeli and Scandura, 2017). Organizational constituents are influenced through ethical leader's modelling, character shaping abililities and persuading power. Reynolds (2008) suggested that self motivated conscious moral fostering is Moral attentiveness. Jennings et al. (2015) adds to the concept and states that it is a type of moral fostering, which internalizes certain moral values that increase an individual's response time and attentiveness to delicate ethical situations. Due to its self-conscious nature, it specifically addresses the subject's personal drive for finding the right path. Leaders with high levels of moral attentiveness can easily recognize and foresee the sensitivity and implications of an ethically just decesion (Culiberg \& Mihelič, 2016).

Reynolds (2008) differentiated between moral attentiveness, and other similar concepts like moral awareness (Rest, 1986) and moral sensitivity (Sparks and Hunt, 1998) to differentiate them. He argued that moral attentiveness specifically entails recognizing information as moral and immoral through rigorous moral appreciation (Sturm, 2017).

Whitaker and Godwin (2013) Moral attentiveness has been broken down into two different perspectives, in reflective moral attentiveness, moral matters of daily significance are the focus of the study. Whereas, in perceptual moral attentiveness, the moral underpinnings that govern the environment in which these matters unfold are analyzed (Reynolds, Owens, \& Rubenstein, 2012; Sturm, 2017). As both are interlinked, the study of reflective moral attentiveness crosses into the realms of perceptual moral attentiveness. This also infers that moral attentiveness is an automatic response to perceptual attentiveness, and can also be considered as its spillover effect (Reynolds et al., 2012; Sturm, 2017).

As per social learning theory, people get attention from the environment and role models. This is the second step of learning after exposure to certain environment or situation. This attention phase allows them to make cognitions about the situation and get motivated. They By capturing the attentions of the followers and being credible, attractive and legitimate role model ethical leaders assist in promoting the message of affirmative beliefs in their organization (Chughtai, 2015). Therefore, the subordinates become morally attentive after founding their supervisor as ethical and reliable. We propose that the truthfulness, ethical decision making and fair treatment are the features that an ethical leader possesses, the subordinates become attentive on these ethical features.

H2: Ethical Leadership has positive relationship with moral attentiveness.

\section{Moral Attentiveness and Helping Behavior}

Jennings et al. (2015) articulated that moral attentiveness is a self-motivated form of moral fostering. Due to its self-conscious nature, it specifically addresses the subject's personal drive righteousness. As per 
Social learning theory when people get attentive to a certain behavior in the environment, they get motivated to perform or replicate the same behavior. As in moral attentiveness state people give importance to ethics and morality that make it highly likely to behave in moral ways (Reynolds, 2008). Therefore, we further suggest:

H3: Moral attentiveness has positive relationship with helping behavior.

\section{Mediating Role of Moral Attentiveness}

Literature supports that ethical leadership like authentic leadership helps to build a trusting environment (Norman et al. 2010). In this kind of environment employees get better able to get morally attentive to wards ethical and morality. These important attentional state people get more convinced to understand importance of helping behaviors (Tyler and Blader, 2000). They show more concern for others and feel their moral responsibility to help peers while performing their job tasks as well.

Using Social learning theory, we argue that subordinates perceive their ethical leader as role model and they get more attentive on the moral attributes of the ethical leadership behavior including fair treatment, moral decision making and truthfulness (Dulebohn \& Wu, 2016; Bavik et al., (2017). These subordinated get motivated to replicated same behavior based on ethics, morality and others concern. We suggest that this state of moral attentiveness further manifest into helping behaviors that is a highly required employee behavior to maintain a productive performance at workplace.

H4: Moral courage serves to regulate moral attentiveness w.r.t helping behavior in such a way that employees with high levels of moral courage enjoy increased moral attentiveness.

\section{Moderating Role of Moral Courage}

Moral courage is a right behavior which symbolize the presence of principles that defines right action (Davis \& Frederick, 2009). According to Koerner's (2014), despite the pressures from the organization/workplace either from inside or outside moral courage having the fortitude to alter moral intentions into actions to do otherwise. Morally driven individuals, instead of cowering in adversarial situations, stand their ground and uphold their principles for the triumph of the greater good. (Comer and Vega, 2015). Lopez et al. (2014), states that moral courage is a state which requires a sustained and incredible strength to take actions against unethical deeds as well as immoral doings. Worline (2017) contends individuation is a foundational element of moral courage, which enables the individual to separate himself from the herd, and morally thrive in the loneliness of his own mind.

Moral courage is related to moral judgement with the speaking power against those behaviors that can harm or demean others (Gibbs et al. 2016). Positive and beneficiary outcomes in the vein of individual pro-social and ethical doings at the work take rise with the intensity of moral courage (Hannah, Cougle \& Hawkins, 2016). To strengthen the individual's moral meaningfulness, moral compels citizens to take moral action to preserve the sanctity of ethical principles in the work environment. (Hannah \& Kimmey, 2015).

Moral Courage is the cornerstone of authentic ethical behavior because it provides evidence for an individual's internalized moral values, and cements his reputation as an ethical light bearer (Comer \& Sekerka, 2018).

Implying social learning theory, we suggest that subordinates who get morally attentive due to ethical behavior of their supervisors/leaders, indulge in replicating these ethical learnt attributes in the form of helping behavior. We further argue that the morally attentive show more helping behavior when they are highly courageous. They can take any hinderance and challenge of environment by their courageous ability based on moral beliefs. 
H4: Moral courage serves to regulate moral attentiveness w.r.t helping behavior in such a way that employees with high levels of moral courage enjoy increased moral attentiveness.

\section{Methodology}

\section{Sample and Data Collection Procedure}

The theoretical framework of this study was tested by collecting data from the employees of education sector (Both Public and Private), all located within twin cities. Teachers and students are often used as research samples as they are appropriate for generalization and convenient to collect data from.

Common method variance bias if not taken care of may posit serious threats to the outcome of statistical analysis (Podsakoff et al., 2003). Helping behavior of focal respondent was reported by their peers. Second, to avoid social desirability in answering, participants were guaranteed response anonymity. Third, Responses were taken at three-time lags. We distributed 380 questionnaires at time 1 to employees of 11 institutions with their free consent for their responses. We received 348 responses back and these respondents were approached for time 2 response after two weeks. We got 335 responses back at time 2 . We further distributed questionnaires to peers of these 335 respondents and got back 308 peer responses at time 3. After dropping incomplete responses, the final responses were 299 for analysis. 239 were male, $51.21 \%$ were between the ages of 25-42 years and reported an average organizational tenure of 3.58 years.

\begin{tabular}{|lll|}
\hline & Table 1. Demographics \\
\hline Variables & Sample Size (N=299) \\
\hline Gender & Category & Frequency \\
\hline Age & Female & 60 \\
& Male & 239 \\
& $20-30$ & 150 \\
& $31-40$ & 70 \\
& $41-50$ & 30 \\
Education & 51 and above & 49 \\
& Graduate and under & 0 \\
& Master & 25 \\
& MS/M. Phil and & 274 \\
Hierarchical Level & above & 160 \\
& Entry & 110 \\
& Middle & 29 \\
\hline
\end{tabular}

\section{Measures}

Frequently used and well-established scales were adopted for measuring all the study variables. All the variables were measured at a 5-point Likert scale ranging from $1=$ strongly disagree and $5=$ strongly agree. English is the official language of Pakistan and is widely understood and used so the questionnaires were distributed in the English language. Previous studies have also used questionnaires in the English language and did not face any language-related issues (Fatima, Majeed \& Shah, 2018; Jahanzeb, Fatima \& Malik, 2018). 


\section{Ethical Leadership}

Brown et al. (2005) on a 5-point Likert scale was used to measure ethical leadership perceptions using the 10 -items. An example item is "My leader sets an example of how to do things the right way in terms of ethics". The Cronbach alpha reliability of this scale was 0.89 .

\section{Moral Attentiveness}

Reynold (2008) was used to measure moral attentiveness consisting of 10-item scale. The alpha reliability for this scale is 0.74 .

\section{Moral Courage}

Sean, Hannah and Bruce and Avolio (2010) scale was used to measure the courageous behaviors consisting of 4 items scale. Sample item includes: "I will confront my peers if they commit an unethical act". Responses were obtained from 5-point scale ranging from 1 strongly disagree to 5 strongly agree. The Cronbach alpha reliability for this variable was 0.85 .

\section{Helping Behavior}

A 6-item scale of Den Hortog \& Dehoog (2007) was used to measure helping behavior. This variable was peer rated to address method bias and social desirability bias. The sample item was "He/she helps others when it is clear their workload is too high ". The Cronbach alpha reliability was .70 for this measure after dropping one low loaded item.

\section{Control Variables}

We conducted one-way analysis of variance test to identify those demographic variables which have a significant relationship with study variables. The results showed that no demographic variable was found significant for any study variable.

\section{Data Analysis Techniques}

After treating missing values and analyzing normality of data descriptive statistics was done on SPSS. The reliability and validity of measures were examined followed by model testing using Haye's PROCESS macro.

\section{Confirmatory Factor Analysis}

The current study conducted a confirmatory factor analysis to establish the convergent and discriminant validity of all the study variables. The observed variables were loaded on their respective latent variables; the factor loadings were greater than 0.4 for all the observed variables. This resulted in the establishment of convergent validity.

Furthermore, discriminant validity was tested by checking the model fit indices. The four-factor model showed better model fit statistics with $\chi^{2}=734, \mathrm{df}=303$ and $\chi^{2} / \mathrm{df}=2.42, \mathrm{CFI}=0.92, \mathrm{IFI}=0.92$, TLI $=0.90$, and RMSEA $=0.05$ as compared to the one-factor model with fit indices $\chi^{2}=2316, \mathrm{df}=310$ and $\chi 2 / \mathrm{df}=7.47, \mathrm{CFI}=0.56, \mathrm{IFI}=0.57, \mathrm{TLI}=0.51$, and RMSEA $=0.14$. Researchers are of the view that proposed model will be good if p-value $>0.05$ for $\chi^{2}$, CFI, IFI, and TLI $>0.80$ and RMSEA $<0.08$ (Yu, 2002). All variables showed average variance extracted (AVE) greater that .45 that shows required content validity for each measure. 
Table 2. Confirmatory Factor Analysis

\begin{tabular}{|ccccc|}
\multicolumn{5}{c}{ Factor Loadings } \\
\hline & EL & MA & MC & HB \\
\hline item 1 & 0.678 & 0.898 & 0.854 & 0.699 \\
item 2 & 0.786 & 0.799 & 0.765 & 0.788 \\
item 3 & 0.768 & 0.756 & 0.749 & 0.773 \\
item 4 & 0.698 & 0.854 & 0.811 & 0.767 \\
item 5 & 0.732 & 0.834 & 0.801 \\
item 6 & 0.755 & 0.799 \\
item 7 & 0.771 & \\
item 8 & 0.778 & \\
item9 & 0.798 & \\
item 10 & 0.834 & \\
$\chi 2=734, \mathrm{df}=303$ and $\chi 2 / \mathrm{df}=2.42, \mathrm{CFI}=0.92, \mathrm{IFI}=0.92, \mathrm{TLI}=0.90$, \\
\multicolumn{5}{c}{ and RMSEA = 0.05 }
\end{tabular}

\section{Bivariate Correlate Analysis}

Table 1 shows the mean, standard deviation, reliability, and correlation. The Cronbach alpha value for all the study variables was greater than 0.7 . The correlation results showed that ethical leadership is significantly related with moral attentiveness $(r=0.29, p<0.001)$, helping behavior $(r=0.22, p<0.001)$, and moral courage $(r=0.37, p<0.001)$. Moral attentiveness showed significant correlation with helping behavior $(r=0.28, p<0.001)$ and moral courage $(r=0.15, p<0.001)$. Moreover, moral courage showed significant correlation with moral courage $(r=0.19, p<0.001)$.

Table 3. Descriptive Statistics, Correlation and Reliability

\begin{tabular}{|llcccccc|}
\hline & Variable & $\mathbf{M}$ & SD & $\mathbf{1}$ & $\mathbf{2}$ & $\mathbf{3}$ & $\mathbf{4}$ \\
\hline 1 & Ethical Leadership & 3.69 & .86 & $(.89)$ & & & \\
2 & Moral Attentiveness & 3.26 & .92 & $.29 * *$ & $(.74)$ & & \\
3 & Helping Behavior & 3.49 & 1.11 & $.22^{* *}$ & $.28^{* *}$ & $(.70)$ & \\
4 & Moral Courage & 3.72 & 1.02 & $.37^{* *}$ & $.15^{* *}$ & $.19^{* *}$ & $(.85)$ \\
\hline
\end{tabular}

\section{Hypotheses Testing}

Table 2 shows the bootstrap results for Total, direct and indirect effects. The results showed that ethical leadership is positively related with helping behavior $(\beta=0.29, p<.001)$ in the absence of mediator that supports hypothesis 1 . Ethical leadership also showed positive relationship with moral attentiveness $(\beta=$ $0.31, p<.001)$ and moral attentiveness showed a positive impact on helping behavior $(\beta=0.28, p<.001)$ that supported hypotheses 2 and 3 respectively.

The bootstrap results for indirect effect at $95 \%$ confidence interval proved that moral attentiveness significantly mediates the relationship between ethical leadership and helping behavior (indirect effect $=$ $0.09), \mathrm{CI}[0.03,0.17]$ that supports mediation hypothesis $\mathrm{H} 4$. 
Table 4 Bootstrapping Results for Total, Direct and Indirect Effects

(95\% Bias Corrected Confidence Interval method)

\begin{tabular}{|c|c|c|c|c|}
\hline Paths & Estimate & S.E & $\begin{array}{l}\text { LLC } \\
\text { I }\end{array}$ & ULCI \\
\hline \multicolumn{5}{|l|}{ Total Effect } \\
\hline H1: Ethical Leadership $\rightarrow$ Helping Behaviors & $.29 * *$ & .06 & .15 & .42 \\
\hline \multicolumn{5}{|l|}{ Direct Effects } \\
\hline H2: Ethical Leadership $\rightarrow$ Moral Attentiveness & $.31 * *$ & .05 & .20 & .43 \\
\hline H3: Moral Attentiveness $\rightarrow$ Helping Behavior & $.28 * *$ & .06 & .15 & .41 \\
\hline $\begin{array}{l}\text { Ethical leadership } \rightarrow \text { Moral Attentiveness } \rightarrow \text { Helping } \\
\text { Behavior }\end{array}$ & $.20 * *$ & .03 & .05 & .37 \\
\hline \multicolumn{5}{|l|}{ Indirect Effect } \\
\hline & $\begin{array}{l}\text { Indirect } \\
\text { effect }\end{array}$ & S.E & LLCI & ULCI \\
\hline $\begin{array}{l}\text { H4: Exploitative Leadership } \rightarrow \text { Emotional Complexity } \rightarrow \\
\text { Psychological Distress }\end{array}$ & .09 & .03 & .03 & .17 \\
\hline
\end{tabular}

Note: N=299; Bootstrap sample size $=5000, B C 95 \%$ CI= Bias corrected confidence Intervals. $L L=$ Lower Limit, UL=Upper limit. *p<.05, **p<.01

Table 5 Moderation Analysis

\begin{tabular}{|lllll|}
\hline Moderator: Moral Courage & & & & \\
\hline Constant & & $\boldsymbol{\beta}$ & S.E & $\Delta \boldsymbol{R}^{\mathbf{2}}$ \\
\hline Moral Attentiveness & & 3.46 & .05 & \\
Moral Courage & $.33^{* *}$ & .06 & \\
H5 Moral Attentiveness x Moral Courage & $.15^{*}$ & .05 & \\
Conditional Effects & $.24^{* *}$ & .05 & $.042^{* *}$ \\
Moral Courage Low $-1 S D(-1.02)$ & Effect & S.E & LLCI & ULCI \\
Moral Courage Medium $M(.00)$ & .09 & .08 & .08 & .25 \\
Moral Courage High $+1 S D(+1.02)$ & .33 & .06 & .21 & .45 \\
\hline
\end{tabular}

$\mathrm{N}=299 * \mathrm{p}<.05, \mathrm{p}^{* *<.01}$, Bootstrap sample size $=5000$

$\mathrm{EL}=$ Ethical leadership, MATT $=$ Moral Attentiveness, $\mathrm{WHB}=$ Workplace Helping Behavior, $\mathrm{LL}=$ Lower limit, $\mathrm{UL}=$ Upper limit, $\mathrm{CI}=$ Confidence interval

For moderation hypotheses testing, moral attentiveness and the moderator moral courage both were centered about mean following Aiken and West (1991). The bootstrap results for the moderation of moral courage between moral attentiveness and helping behavior showed an incremental variance of $4.2 \%$ in helping behavior due to the interaction of moral attentiveness and moral courage $\left(\Delta \mathrm{R}^{2}=.042, \mathrm{p}<.001\right)$. Slope test further revealed that the relation between moral attentiveness and helping behavior is weak at -1 standard deviation from the mean $(\beta=0.09)$, CI $[.08, .25]$ and stronger at +1 standard deviation from the mean $(\beta=0.58)$, CI $[.40, .76]$ which supported H5. The results of the moderation hypothesis are given in table 3

\section{Discussion}

Ethical leaders are those influential authorities whose conducts are based on moral philosophy (Trevino, Hartman, \& Brown, 2014). Ethical leadership is an individual's display of acquired morality through his own subtle actions and interpersonal interactions with the organizational environment (Dulebohn \& Wu, 2016). When leaders depict as moral role models and continuously encourage and impart ethical values in their followers helping behavior is increased. Followers because of learned moral values may develop 
intrinsic motivation fueled by moral courage thus enhancing ethical practices. Followers closely observe the behaviors of their leaders while taking decision in similar circumstances, therefore, enhancing moral attentiveness leading towards better judgment. It is further suggested that helping behavior within the rule sets of the organization is extracted from the ethical leadership conduct. The findings of the study are in line with the underpinning theory as leader gains attention of the followers. After internalizing the values they reciprocate theirs believes and translate them into their behaviors (RFB).

\section{Limitations and Future Research Directions}

This research paper presents different beneficial findings but this study has several limitations that provide arena for future researches. These limitations include number of sample size along with the population itself. Data of employees were used only for analysis, it may include sample from other segments like students, household consumers and professionals for further insights. Secondly, cross sectional design was deployed; future studies can use longitudinal design for changing moral schemata's individuals over the period. Consumer decision making style moderated with the from the personality type of consumers and religious belonging will have great contribution for the body of knowledge. Future researcher can use cross religious examination to have better understanding of the topic.

\section{References}

Bandura, A. (1977). Self-efficacy: toward a unifying theory of behavioral change. Psychological review, $84(2), 191$.

Bandura, A. (1986). The explanatory and predictive scope of self-efficacy theory. Journal of social and clinical psychology, 4(3), 359-373.

Bandura, A. (1991). Social cognitive theory of self-regulation. Organizational behavior and human decision processes, 50(2), 248-287.

Bandura, A., \& Walters, R. H. (1963). Social learning and personality development.

Bandura, A., \& Walters, R. H. (1977). Social learning theory (Vol. 1): Prentice-hall Englewood Cliffs, NJ.

Bavik, A., Bavik, Y. L., \& Tang, P. M. (2017). Servant leadership, employee job crafting, and citizenship behaviors: A cross-level investigation. Cornell Hospitality Quarterly, 58(4), 364-373.

Bedi, A., Alpaslan, C. M., \& Green, S. (2016). A meta-analytic review of ethical leadership outcomes and moderators. Journal of Business Ethics, 139(3), 517-536.

Brown, M. E., \& Treviño, L. K. (2006). Ethical leadership: A review and future directions. The leadership quarterly, 17(6), 595-616.

Brown, M. E., Treviño, L. K., \& Harrison, D. A. (2005). Ethical leadership: A social learning perspective for construct development and testing. Organizational behavior and human decision processes, 97(2), 117-134.

Chughtai, A., Byrne, M., \& Flood, B. (2015). Linking ethical leadership to employee well-being: The role of trust in supervisor. Journal of Business Ethics, 128(3), 653-663.

Ciulla, J. B. (2009). Leadership and the ethics of care. Journal of Business Ethics, 88(1), 3-4.

Comer, D. R., \& Sekerka, L. E. (2018). Keep calm and carry on (ethically): Durable moral courage in the workplace. Human Resource Management Review, 28(2), 116-130.

Comer, D. R., \& Vega, G. (2011). The relationship between the personal ethical threshold and workplace spirituality. Journal of Management, Spirituality \& Religion, 8(1), 23-40.

Comer, D. R., \& Vega, G. (2015). Moral courage in organizations: Doing the right thing at work. ME Sharpe.

Culiberg, B., \& Mihelič, K. K. (2016). Three ethical frames of reference: insights into M illennials' ethical judgements and intentions in the workplace. Business Ethics: A European Review, 25(1), 94-111.

De Hoogh, A. H. B., \& Den Hartog, D. N. (2008). Ethical and Despotic Leadership, Relationships with leader's Social Responsibility, Top Management Team Effectiveness and Subordinates' Optimism: A Multi-Method Study. The Leadership Quarterly, 19 297-311. http://dx.doi.org/10.1016/j.leaqua.2008.03.002 
De Hoogh, A. H., \& Den Hartog, D. N. (2009). Neuroticism and locus of control as moderators of the relationships of charismatic and autocratic leadership with burnout. Journal of Applied Psychology, 94(4), 1058.

DeHart-Davis, L. (2017). Creating effective rules in public sector organizations. Georgetown University Press.

Dulebohn, J. H., Wu, D., \& Liao, C. (2017). Does liking explain variance above and beyond LMX? A meta-analysis. Human Resource Management Review, 27(1), 149-166.

Fatima, T., Majeed, M., \& Shah, S. Z. (2018). Jeopardies of aversive leadership: a conservation of resources theory approach. Frontiers in psychology, 9, 1935.

Gibbs, J. C. (2019). Moral development and reality: Beyond the theories of Kohlberg, Hoffman, and Haidt. Oxford University Press.

Hannah, S. T., \& Avolio, B. J. (2010). Ready or not: How do we accelerate the developmental readiness of leaders?. Journal of Organizational Behavior, 31(8), 1181-1187.

Hannah, S. T., \& Avolio, B. J. (2010). Ready or not: How do we accelerate the developmental readiness of leaders?. Journal of Organizational Behavior, 31(8), 1181-1187.

Hannah, S. T., Avolio, B. J., \& Walumbwa, F. O. (2011). Relationships between authentic leadership, moral courage, and ethical and pro-social behaviors. Business Ethics Quarterly, 21(4), 555-578.

Hannah, S. T., Avolio, B. J., \& Walumbwa, F. O. (2011). Relationships between authentic leadership, moral courage, and ethical and pro-social behaviors. Business Ethics Quarterly, 21(4), 555-578.

Hirst, G., Walumbwa, F., Aryee, S., Butarbutar, I., \& Chen, C. J. H. (2016). A multi-level investigation of authentic leadership as an antecedent of helping behavior. Journal of Business Ethics, 139(3), 485-499.

Jahanzeb, S., Fatima, T., \& Malik, M. A. R. (2018). Supervisor ostracism and defensive silence: a differential needs approach. European Journal of Work and Organizational Psychology, 27(4), 430440.

Jennings, P. L., Mitchell, M. S., \& Hannah, S. T. (2015). The moral self: A review and integration of the literature. Journal of Organizational Behavior, 36(S1), S104-S168.

Kidder, R. M. (2005). Moral courage.

Koerner, M. M. (2014). Courage as identity work: Accounts of workplace courage. Academy of Management Journal, 57(1), 63-93.

Mājah, I., \& bin Yaz̄ì, A. A. A. M. (1952). Sunan Ibn Mājah. Bayrūt: Dār Iḥyā'al-Turāth al'Arabī, 2(1414), 4229.

Mayer, D. M., Kuenzi, M., Greenbaum, R., Bardes, M., \& Salvador, R. B. (2009). How low does ethical leadership flow? Test of a trickle-down model. Organizational behavior and human decision processes, 108(1), 1-13.

Norman, S. M., Avey, J. B., Nimnicht, J. L., \& Graber Pigeon, N. (2010). The interactive effects of psychological capital and organizational identity on employee organizational citizenship and deviance behaviors. Journal of Leadership \& Organizational Studies, 17(4), 380-391.

Palanski, M. E., Cullen, K. L., Gentry, W. A., \& Nichols, C. M. (2015). Virtuous leadership: Exploring the effects of leader courage and behavioral integrity on leader performance and image. Journal of Business Ethics, 132(2), 297-310.

Palanski, M. E., Cullen, K. L., Gentry, W. A., \& Nichols, C. M. (2015). Virtuous leadership: Exploring the effects of leader courage and behavioral integrity on leader performance and image. Journal of Business Ethics, 132(2), 297-310.

Peng, J. C., \& Lin, J. (2017). Mediators of ethical leadership and group performance outcomes. Journal of Managerial Psychology.

Pircher Verdorfer, A., \& Peus, C. (2019). Leading by example: Testing a moderated mediation model of ethical leadership, value congruence, and followers' openness to ethical influence. Business Ethics: A European Review.

Podsakoff, N. P., Podsakoff, P. M., MacKenzie, S. B., Maynes, T. D., \& Spoelma, T. M. (2014). Consequences of unit-level organizational citizenship behaviors: A review and recommendations for future research. Journal of Organizational Behavior, 35(S1), S87-S119. 
Podsakoff, P. M., MacKenzie, S. B., Lee, J. Y., \& Podsakoff, N. P. (2003). Common method biases in behavioral research: a critical review of the literature and recommended remedies. Journal of applied psychology, 88(5), 879 .

Podsakoff, P. M., MacKenzie, S. B., Paine, J. B., \& Bachrach, D. G. (2000). Organizational citizenship behaviors: A critical review of the theoretical and empirical literature and suggestions for future research. Journal of management, 26(3), 513-563.

Rest, J. R.: 1986, Moral Development: Advances in Research andTheory (University of Minnesota Press, Minneapolis).

Reynolds, S. J. (2008). Moral attentiveness: Who pays attention to the moral aspects of life? Journal of Applied Psychology, 93(5), 1027.

Reynolds, S. J., Owens, B. P., \& Rubenstein, A. L. (2012). Moral stress: Considering the nature and effects of managerial moral uncertainty. Journal of business ethics, 106(4), 491-502.

Schaufeli, W., \& De Witte, H. (2017). Work Engagement: Real or Redundant?.

Sekerka, L. E., \& Bagozzi, R. P. (2007). Moral courage in the workplace: Moving to and from the desire and decision to act. Business Ethics: A European Review, 16(2), 132-149.

Sekerka, L. E., Bagozzi, R. P., \& Charnigo, R. (2009). Facing ethical challenges in the workplace: Conceptualizing and measuring professional moral courage. Journal of Business Ethics, 89(4), 565.

Simola, S. (2018). Fostering collective growth and vitality following acts of moral courage: A general system, relational psychodynamic perspective. Journal of Business Ethics, 148(1), 169-182.

Sparks, J. R., \& Hunt, S. D. (1998). Marketing researcher ethical sensitivity: Conceptualization, measurement, and exploratory investigation. Journal of Marketing, 62(2), 92-109.

Sturm, R. E. (2017). Decreasing unethical decisions: The role of morality-based individual differences. Journal of business ethics, 142(1), 37-57.

Trevino, L. K., Hartman, L. P., \& Brown, M. (2000). Moral person and moral manager: How executives develop a reputation for ethical leadership. California management review, 42(4), 128-142.

Tyler, T. R., \& Blader, S. L. (2000). Cooperation in groups: Procedural justice, social identity, and behavioral engagement. Psychology press.

Tyler, T. R., \& Blader, S. L. (2005). Can businesses effectively regulate employee conduct? The antecedents of rule following in work settings. Academy of Management Journal, 48(6), 1143-1158.

Whitaker, B. G., \& Godwin, L. N. (2013). The antecedents of moral imagination in the workplace: A social cognitive theory perspective. Journal of Business Ethics, 114(1), 61-73.

Whitaker, B. G., \& Godwin, L. N. (2013). The antecedents of moral imagination in the workplace: A social cognitive theory perspective. Journal of business ethics, 114(1), 61-73.

Worline, M. C., Wrzesniewski, A., \& Rafaeli, A. (2002). Courage and work: Breaking routines to improve performance. In R. Lord, R. Klimoski, \& R. Kanfer (Eds.), Emotions at work (pp. 295-330). San Francisco, CA: Jossey-Bass.

Zheng, D., Witt, L. A., Waite, E., David, E. M., van Driel, M., McDonald, D. P., ... \& Crepeau, L. J. (2015). Effects of ethical leadership on emotional exhaustion in high moral intensity situations. The Leadership Quarterly, 26(5), 732-748. 


\section{Annexure-I}

\section{Demographics}

Name of the Company:

Gender: $\square$ Male $\square$ Female

Age:

Qualification: $\square$ Intermediate $\square$ Bachelors $\quad \square$ Masters

Doctorate

Please write your Month of Birth then your name initials (For example if you are born in July and your name is Muhammad Akram then write 07MA) :

Hierarchical Level:

$\square$ Entry level $\quad \square$ Middle level $\quad \square$ Senior level

\begin{tabular}{|l|l|l|l|c|}
\hline 1= Strongly Disagree & 2= Disagree & 3= Neutral & 4= Agree & 5= Strongly Agree \\
\hline
\end{tabular}

Ethical leadership (Brown et al, 2005).

How do think about your leader.

\begin{tabular}{|c|l|c|c|c|c|c|}
\hline 1 & My Leader conducts his/her personal life in an ethical manner & $\mathbf{1}$ & $\mathbf{2}$ & $\mathbf{3}$ & $\mathbf{4}$ & $\mathbf{5}$ \\
\hline 2 & $\begin{array}{l}\text { My Leader defines success not just by results but also the way that } \\
\text { they are obtained. }\end{array}$ & $\mathbf{1}$ & $\mathbf{2}$ & $\mathbf{3}$ & $\mathbf{4}$ & $\mathbf{5}$ \\
\hline 3 & My Leader listens to what employees have to say. & $\mathbf{1}$ & $\mathbf{2}$ & $\mathbf{3}$ & $\mathbf{4}$ & $\mathbf{5}$ \\
\hline 4 & My Leader disciplines employees who violate ethical standards. & $\mathbf{1}$ & $\mathbf{2}$ & $\mathbf{3}$ & $\mathbf{4}$ & $\mathbf{5}$ \\
\hline 5 & My Leader makes fair and balanced decisions. & $\mathbf{1}$ & $\mathbf{2}$ & $\mathbf{3}$ & $\mathbf{4}$ & $\mathbf{5}$ \\
\hline 6 & My Leader can be trusted. & $\mathbf{2}$ & $\mathbf{3}$ & $\mathbf{4}$ & $\mathbf{5}$ \\
\hline 7 & My Leader discusses business ethics or values with employee. & $\mathbf{1}$ & $\mathbf{2}$ & $\mathbf{3}$ & $\mathbf{4}$ & $\mathbf{5}$ \\
\hline 8 & $\begin{array}{l}\text { My Leader sets an example of how to do things the right way in } \\
\text { terms of ethics }\end{array}$ & $\mathbf{1}$ & $\mathbf{2}$ & $\mathbf{3}$ & $\mathbf{4}$ & $\mathbf{5}$ \\
\hline 9 & My Leader has the best interest of employees in mind. & $\mathbf{1}$ & $\mathbf{2}$ & $\mathbf{3}$ & $\mathbf{4}$ & $\mathbf{5}$ \\
\hline 10 & $\begin{array}{l}\text { My Leader when making decisions asks "what is the right thing to } \\
\text { do?" }\end{array}$ & $\mathbf{1}$ & $\mathbf{2}$ & $\mathbf{3}$ & $\mathbf{4}$ & $\mathbf{5}$ \\
\hline
\end{tabular}

Moral Courage (Sean T. Hannah and Bruce J. Avolio (2010))

\begin{tabular}{|l|c|c|c|c|}
\hline 1= Strongly Disagree & 2= Disagree & 3= Neutral & 4= Agree & 5= Strongly Agree \\
\hline
\end{tabular}

How do you rate the following statements?

\begin{tabular}{|l|l|l|l|l|l|l|}
\hline \multicolumn{2}{|l|}{ Moral Courage } & $\mathbf{1}$ & $\mathbf{2}$ & $\mathbf{3}$ & $\mathbf{4}$ & $\mathbf{5}$ \\
\hline 1 & I will confront my peers if they commit an unethical act & $\mathbf{1}$ & $\mathbf{2}$ & $\mathbf{3}$ & $\mathbf{4}$ & $\mathbf{5}$ \\
\hline 2 & I will confront a leader if she/she commits an unethical act & $\mathbf{1}$ & $\mathbf{2}$ & $\mathbf{3}$ & $\mathbf{4}$ & $\mathbf{5}$ \\
\hline 3 & I will always state my views about ethical issues to my leaders & $\mathbf{1}$ & $\mathbf{2}$ & $\mathbf{3}$ & $\mathbf{4}$ & $\mathbf{5}$ \\
\hline 4 & $\begin{array}{l}\text { I will go against the group's decision whenever it violates my ethical } \\
\text { standards }\end{array}$ & $\mathbf{3}$ &
\end{tabular}


Moral Attentiveness (Reynolds, 2008).

\begin{tabular}{|c|c|c|c|c|c|c|}
\hline $\begin{array}{c}1= \\
\begin{array}{c}\text { Strongly } \\
\text { Disagree }\end{array}\end{array}$ & $\begin{array}{c}2= \\
\text { Somewhat } \\
\text { Disagree }\end{array}$ & $\begin{array}{c}3= \\
\text { Slightly } \\
\text { Disagree }\end{array}$ & $\begin{array}{c}4= \\
\text { Neutral }\end{array}$ & $\begin{array}{c}\text { Slightly } \\
\text { Agree }\end{array}$ & $\begin{array}{c}\text { 6= Somewhat } \\
\text { Agree }\end{array}$ & $\begin{array}{c}7=\text { Strongly } \\
\text { Agree }\end{array}$ \\
\hline
\end{tabular}

\begin{tabular}{|c|l|c|c|c|c|c|c|c|}
\hline \multicolumn{1}{|l|}{ Perceptual Moral Attentiveness } & $\mathbf{1}$ & $\mathbf{2}$ & $\mathbf{3}$ & $\mathbf{4}$ & $\mathbf{5}$ & $\mathbf{6}$ & $\mathbf{7}$ \\
\hline 1 & I frequently encounter ethical situations. & $\mathbf{1}$ & $\mathbf{2}$ & $\mathbf{3}$ & $\mathbf{4}$ & $\mathbf{5}$ & $\mathbf{6}$ & $\mathbf{7}$ \\
\hline 2 & I rarely face ethical dilemmas & $\mathbf{1}$ & $\mathbf{2}$ & $\mathbf{3}$ & $\mathbf{4}$ & $\mathbf{5}$ & $\mathbf{6}$ & $\mathbf{7}$ \\
\hline 3 & In a typical day, I face several ethical dilemmas & $\mathbf{1}$ & $\mathbf{2}$ & $\mathbf{3}$ & $\mathbf{4}$ & $\mathbf{5}$ & $\mathbf{6}$ & $\mathbf{7}$ \\
\hline 4 & $\begin{array}{l}\text { My life has been filled with one moral predicament after } \\
\text { another }\end{array}$ & $\mathbf{1}$ & $\mathbf{2}$ & $\mathbf{3}$ & $\mathbf{4}$ & $\mathbf{5}$ & $\mathbf{6}$ & $\mathbf{7}$ \\
\hline 5 & $\begin{array}{l}\text { Many of the decisions that I make have ethical dimensions to } \\
\text { them. }\end{array}$ & $\mathbf{1}$ & $\mathbf{2}$ & $\mathbf{3}$ & $\mathbf{4}$ & $\mathbf{5}$ & $\mathbf{6}$ & $\mathbf{7}$ \\
\hline 6 & $\begin{array}{l}\text { I } \text { often must choose between doing what's right and doing } \\
\text { something that's wrong. }\end{array}$ & $\mathbf{1}$ & $\mathbf{2}$ & $\mathbf{3}$ & $\mathbf{4}$ & $\mathbf{5}$ & $\mathbf{6}$ & $\mathbf{7}$ \\
\hline Reflective Moral Attentiveness & $\mathbf{1}$ & $\mathbf{2}$ & $\mathbf{3}$ & $\mathbf{4}$ & $\mathbf{5}$ & $\mathbf{6}$ & $\mathbf{7}$ \\
\hline 1 & I often reflect on the moral aspects of my decisions & $\mathbf{1}$ & $\mathbf{2}$ & $\mathbf{3}$ & $\mathbf{4}$ & $\mathbf{5}$ & $\mathbf{6}$ & $\mathbf{7}$ \\
\hline 2 & I like to think about ethics & $\mathbf{1}$ & $\mathbf{2}$ & $\mathbf{3}$ & $\mathbf{4}$ & $\mathbf{5}$ & $\mathbf{6}$ & $\mathbf{7}$ \\
\hline 3 & I think about the morality of my actions almost every day & & & & \\
\hline 4 & I regularly think about the ethical implications of my decisions & &
\end{tabular}

Helping Behavior (Den Hortog \& Dehoog (2007))

1= Strongly Disagree 2= Disagree
\begin{tabular}{|l|l|c|c|c|c|c|}
\hline \multicolumn{1}{|c|}{ 3= Neutral } & 4= Agree & \multicolumn{3}{|c|}{$5=$ Strongly Agree } \\
\hline 1 & Helps others when it is clear their workload is too high & $\mathbf{1}$ & $\mathbf{2}$ & $\mathbf{3}$ & $\mathbf{4}$ & $\mathbf{5}$ \\
\hline 2 & $\begin{array}{l}\text { Takes the initiative to help orient newcomers in the organization even } \\
\text { though it is not required }\end{array}$ & $\mathbf{1}$ & $\mathbf{2}$ & $\mathbf{3}$ & $\mathbf{4}$ & $\mathbf{5}$ \\
\hline 3 & Lends a helping hand to coworkers when needed & $\mathbf{1}$ & $\mathbf{2}$ & $\mathbf{3}$ & $\mathbf{4}$ & $\mathbf{5}$ \\
\hline 4 & Willingly assists others in meeting deadlines or requirements & $\mathbf{1}$ & $\mathbf{2}$ & $\mathbf{3}$ & $\mathbf{4}$ & $\mathbf{5}$ \\
\hline 5 & Thinks of ways to improve collaboration within the organization & $\mathbf{1}$ & $\mathbf{2}$ & $\mathbf{3}$ & $\mathbf{4}$ & $\mathbf{5}$ \\
\hline 6 & Works with others wherever possible to help improve the image & $\mathbf{1}$ & $\mathbf{2}$ & $\mathbf{3}$ & $\mathbf{4}$ & $\mathbf{5}$ \\
\hline
\end{tabular}

